\title{
AN EVALUATION OF CLIMBING AS A SPORT TOURIST ACTIVITY, USING THE ROBINSON AND GAMMON (2004) CONCEPTUAL FRAMEWORK
}

\section{Tom Robinson*}

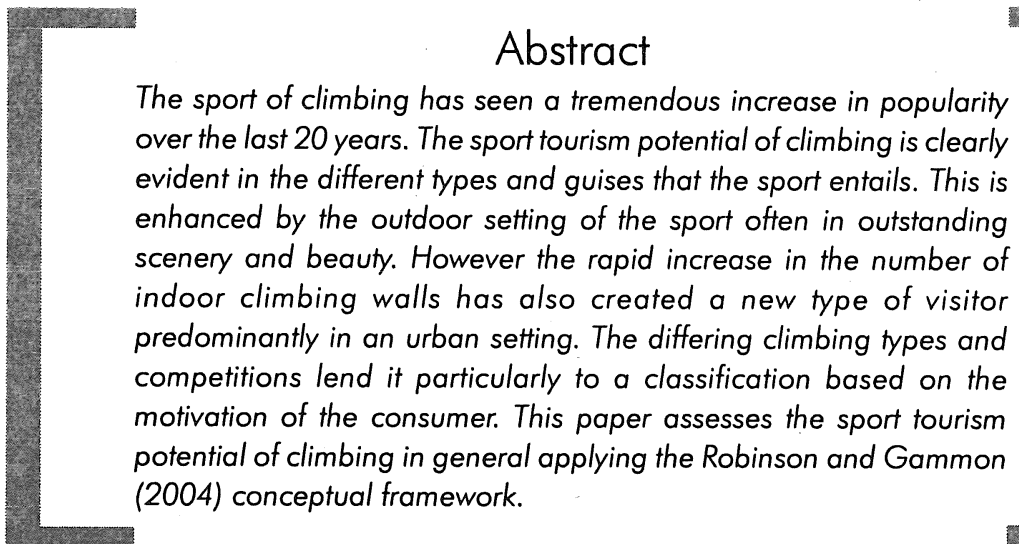

Key words: Climbing, Sport Tourism, Motivation, Sport Tourism Framework.

* Senior Lecturer \& Researcher, Hanze Institute for Sport Studies, Hanze Professional University of Groningen, The Netherlands, Email: t.w.robinson@pl.hanze.nl 


\section{Introduction}

Climbing in many ways encapsulates the very essence of the sport tourism phenomena. Climbing has seen a tremendous increase in popularity over the last 20 years. Reasons for this expansion can be traced to the introduction of sport climbing and the increased and improved competition calendar for many different types of climbing events. In addition the improved mobility and health related effects of climbing have also led to an increase in participation rates for both active and passive climbers. These aspects as identified by Kurtzman and Zauhar (1995) illustrate well the changing dynamics of climbing as a sport tourism activity.

Within climbing alone there is such a diversity of climbing types, methods and places, that, like sport tourism, identifying a particular profile or typology is virtually impossible. This ranges from recreational to competitive and from indoor to outdoor climbing activities. It is, like so many sports reinventing itself and can now in its various forms be practised throughout the year in many different weather conditions. Such is the variable nature of climbing the sport tourism components are difficult to assess and thus any attempt to analyse the area is fraught with difficulties.

There does not seem to be anywhere left on the planet where someone has not climbed. If there is nowhere to climb then artificial means of climbing are invented and differing sport climbing 'themes' for competition and recreation are created. This 'sportization' of the planet as identified by Maguire (2004) epitomises, (through climbing) the concept of globalisation through internationalisation, liberalisation, universalisation of culture, westernisation and deterritorialisation (as also illustrated by Houlihan 2004).

From a sport tourism perspective not only are many of these climbs in outstanding areas of beauty they are also part of an urban sport tourism movement involving frequent visits to indoor and outdoor climbing halls and walls in many cities. In addition many climbing activities are associated with groups, clubs and societies. It is social in nature as well as being the lone individual pursuit as it is so often perceived.

The figures to estimate the numbers of climbers is far from clear. According to the National Survey on Recreation and the Environment (Cordell, 2004), there are 8.8 million rock climbing participants in the United States. In the United Kingdom various studies indicated that climbing was the fastest growing sport in England and Wales with an estimated 700,000 participants. This rose to 1.27 
million in a survey of 2003 by the British Mountaineering Council (BMC). There has been no systematic attempt to specifically measure the climbing population; however the overall trend in European countries appears to one of steady growth.

There are a number of difficulties in conducting research into climbing. These focus on

- The definition of a "climber". According to the Health and Safety Commission (1996), Adventure Activity Licensing Regulations, climbing is:

"Movement over difficult terrain which requires the use of hands as well as feet and where safety requires either the use of equipment or the skills and techniques of a rock climber"

... but what about bouldering and all the various other 'sport' climbing activities?

- Whether a 'climber' is 'active'. Participation rates vary enormously.

- The informal nature of the sport. Many climbers do not register their interest. In the UK over $20 \%$ of climbers are not involved with any club.

- Many climbers are members of more than one club.

However the increase in popularity of the sport is obvious by various secondary developments as identified by the BMC participation survey 2003;

- the rapid increase in number of retail outlets

- increased pressure for parking spaces at climbing venues

- membership figures (year-on-year increases in membership)

- increased media coverage

- increased fashion interest in outdoor clothing

Much of the media interest focuses on rock climbing at specific high profile mountains and mountainous areas. However there is far more to climbing than these minority groups receiving this media hype e.g. Mount Everest and K2. The sport tourism potential of large numbers of participants involved, at many travel destinations, in competitions and through recreational climbing activities is enormous. 


\section{Why Climb?}

Climbing, defined as to move upward on or mount, especially by using the hands and feet or the feet cannot alone account for the multiple types and climbing methods practiced. For example mountain climbing involves special equipment and techniques and does not incorporate specific skills and characteristics associated by the majority of sport climbing methods. Climbing has evolved a system of classification and grades based on degrees of difficulty and length of stay. Climbers grade the difficulty of the routes they climb. The grading system used varies from country to country (and region) and according to the style of climb (see UKclimbing.com for more information).

The official body for climbing is the Union Internationale Des Association D'Alpinism (UIAA). The UIAA is a recognised International Federation by the International Olympic Committee (IOC) and a member of the General Association of Recognised International Sports Federations (GAISF) and the International World Games Association (IWGA). The UIAA has 97 member associations in 68 different countries representing over 2.5 million committed individual members, and the interests of 10's of millions of participants. Climbing is essentially a participation sport. The possibility for spectators is limited to sport climbing competitions and events. This is administered by a branch of the UIAA, the International Council for Competitive Climbing (ICC), formed in 1997.

Many mountain ascents require a combination of techniques. Continual improved technology has enabled different approaches to climbing. Climbers began to focus on a particular pitch or wall rather than climbing the 'mountain'. Thus a new type of climbing evolved, 'sport' climbing. This emphasises shorter routes, physically difficult movement, bolted protection and involves competition. Initially these competitive events were held at outdoor locations on real rock and began in Europe about 30 years ago as speed climbing events. Within a few years the first indoor climbing walls began to appear as competition climbing on indoor walls had the distinct advantage of being able to control the weather and allow the exact placement of the holds to create new routes. Indoor competitions increased in the early 1980's as climbing walls became popular.

Due to sport climbing's recent popularity climbing walls are now being erected in indoor and outdoor facilities world wide. This increased safety (through the use of a harness) has allowed climbers to attain greater levels of difficulty. Today there are over 3,000 indoor climbing walls holding about 500 climbing competitions each year world-wide (indoorclimbing.com). 
Gradually, various types of shorter route climbing such as bouldering and sport climbing have gained popularity as independent pursuits. Difficulty standards have reached high levels. Bouldering (short low climbs) and sport climbing have become the fastest growing sectors of rock climbing.

Therefore a distinction can be made between two generic types of climbing. Climbing mountains and cliffs as opposeú to sport climbing.

There have been many investigations into the psychological motivations to climb. The motivation to climb is complex. For many it seems that climbing cannot be explained. Such motivational variations lead to a set of multiple motivators at an intrinsic and extrinsic level.

The wide range of physical, psychological and indeed philosophical demands (Mallory's famous explanation as to why he wanted to climb Everest, "because it is there") makes the activity absorbing in a way many other 'sports' are not.

If it is accepted that climbing is in itself a meaningless exercise, then the individual must be seeking some 'deeper' meaning. One must look beyond the activity of climbing 'as a thing in itself'. However there are distinguishable motivations between different types of climbing.

In sport climbing, the use of material on the rock removes the element of danger and allows exploration to the peak of ones performance without the worry of potential injury. As a result, sport climbing has become extremely popular not only to climb but also as a social activity. In addition the number of females taking up sport climbing has also increased adding to the social aspect of this area of the sport. 'Sports' climbing is in many ways the antithesis of traditional climbing. The sports climber is likely to be focused, dedicated and competitive. This is not to say that sport climbing is not physically demanding and psychologically challenging. However, as a consequence of being relatively risk free sport climbing does not allow the individual to explore the major realities of risk, uncertainty, fear and the will to sunvive. The sports climber has no need to develop the sense of 'oneness' with the rock that the traditional climber's life depends on.

The essential nature of extreme traditional climbing is very male and elitist. However, sport climbing is essentially populist. Certainly, the popularity with climbing amongst women in countries such as France is largely due to the removal of risk (www.womenclimbing.com). 
However, for some the motivation to climb reflects deeper and more complex needs. At the simplest level of analysis the motivation to climb might be regarded as arising from the simple enjoyment of movement on rock; becoming aware of the subtleties of balance and the frictional properties of the rock, experiencing the flow of a sequence of moves. Ewart (1985) discusses the reason why people climb and further insight can be obtained from Freischlag and Freischlag (1993), Campbell (1997), Carr (1998), Boyd and Munroe (2003). Also 'Athletic Insight' The Online Journal of Sport Psychology offers an interesting insight into sport psychology. In addition Deci and Ryan (1985), (2000) offer an interesting aspect of sport psychology through self determination theory (and its application to sport and exercise in general) at their website at the Psychology Department, University of Rochester, USA.

Table 1. Extrinsic and Intrinsic reasons to climb based upon based upon Ewart (1985), Magni et al. (1985), Mclntyre (1992), Robinson (1985), Mitchell 1983, Frieschlag and Frieschlag (1993). Meier (1980), Catton (1969), Csikszentmihalyi (1975), (1990) Walter (1984), Rossi and Cereatti (1993), (after Zuckerman).

\begin{tabular}{|c|c|}
\hline Extrinsic reasons to climb & Intrinsic reasons to climb \\
\hline The need for competence and control. & $\begin{array}{l}\text { Developing a better understanding of } \\
\text { oneself. }\end{array}$ \\
\hline The rewards of competition. & $\begin{array}{l}\text { Nostalgia for the simple natural } \\
\text { environment. }\end{array}$ \\
\hline $\begin{array}{l}\text { Sharing an interest with other like- } \\
\text { minded people. Friendship, } \\
\text { companionship. }\end{array}$ & $\begin{array}{l}\text { The climber as a 'visionary' allows the } \\
\text { individual to develop a truer } \\
\text { perspective on their lives. }\end{array}$ \\
\hline To compete with others. & The need for inner harmony. \\
\hline Determination, strength, endurance. & Power of uncertainty. \\
\hline $\begin{array}{l}\text { A 'challenge' against which the } \\
\text { individual can test themselves. }\end{array}$ & Risk and the will to survive. \\
\hline $\begin{array}{l}\text { Simple enjoyment of the physical } \\
\text { activity. }\end{array}$ & $\begin{array}{l}\text { Being 'sensation seekers' who need } \\
\text { high levels of psychological arousal } \\
\text { to avoid boredom. }\end{array}$ \\
\hline $\begin{array}{l}\text { Being an individual, making ones own } \\
\text { choices and relying on their own } \\
\text { resources. }\end{array}$ & $\begin{array}{l}\text { 'Heroes' in the traditional mould } \\
\text { members of a team sacrificed their } \\
\text { chances so that others might succeed } \\
\text { or went to the aid. }\end{array}$ \\
\hline
\end{tabular}




\begin{tabular}{|l|l|}
\hline $\begin{array}{l}\text { Inspired by the idea of reaching a given } \\
\text { summit. }\end{array}$ & $\begin{array}{l}\text { Surrender of the ego and so } \\
\text { rediscover a greater sense of } \\
\text { 'oneness' with the world. }\end{array}$ \\
\hline $\begin{array}{l}\text { For the touristic pleasures natural } \\
\text { scenery, enjoying wilderness, closeness } \\
\text { to nature. The physical setting. }\end{array}$ & $\begin{array}{l}\text { When challenge matches skill levels } \\
\text { and "Flow" results. An enhanced state } \\
\text { of mind through peak experience and } \\
\text { peak performance. }\end{array}$ \\
\hline $\begin{array}{l}\text { The attractive 'image' of climbing being } \\
\text { dangerous and even 'reckless'. }\end{array}$ & $\begin{array}{l}\text { To boost ones sense of self esteem. } \\
\text { The need to have a positive self } \\
\text { image. }\end{array}$ \\
\hline
\end{tabular}

The multiple and complex motivations as to why people climb appear to be grouped into two climbing categories. The relatively simple extrinsic motivations consistent with 'fun' and 'play' of the sports climber compared to dominantly complex intrinsic factors associated with traditional mountaineering. However it is too simplistic to group climbing motivation into 2 categories. Research suggests that motivations also seem to change with experience (see Ewart 1985, Mitchell 1983). Less experienced climbers tend to be extrinsically motivated as opposed to the experienced more intrinsically motivated climbers. Friendship appears to be the main extrinsic motive of any real value. This is interesting in a tourism context where travel with friends to climb is a major factor in the sport tourism decision making process.

\section{Climbing Types and Methods}

The type and methods of climbing are varied and diverse. The sport tourism potential of each one of these is also of course variable. For the purpose of this paper it is suffice to note the variety of types and indicate the diversity of the sport tourism experience possible through the generic title of climbing.

Indoor walls are an increasingly important part of climbing. Indoor climbing and bouldering takes place at sports gyms on artificial walls. Holds are of plastic material and can be made in many shapes and placed in many positions. The heights of the different walls differ from 8 to 20 meters. The highest outdoor climbing wall in The Netherlands is in Groningen (Bjoeks) and is 37 meters high. In Den Hague it is also possible to ice climb indoor throughout the year. This situation is common in many parts of Europe. 
Obviously climbing walls facilitate the excursionist and leisure enthusiast whereas outdoor recreational climbing is more often than not carried out away from home in areas of the countryside either on a day trip or involving an overnight stay. As stated earlier climbing is essentially a participation sport. Competitions in their various guises form a sport tourism component that is little researched but participants are few in number. However some sport climb competitions can generate a large number of spectators e.g. Average World Cup attendance 1500-7000 spectators. The potential numbers who travel independently and climb is significant yet very difficult to evaluate compared to the organised clubs and societies that arrange trips. Tables 2,3, and 4 illustrate the variety of climbing styles, methods and competitions assessing the sport tourism potential for each.

Table 2. Climbing Types

\begin{tabular}{|c|c|}
\hline Climbing types & Sport Tourism Potential \\
\hline $\begin{array}{l}\text { Alpine climbing(Mountaineering) } \\
\text { The pursuit of reaching the top of any earthly } \\
\text { mound by any means necessary. Rock } \\
\text { climbing is just part of this varied pursuit that } \\
\text { might include hiking, snowshoeing, ice } \\
\text { climbing. A common traditional form of } \\
\text { climbing outdoor. Can be dangerous, costly } \\
\text { equipment. }\end{array}$ & $\begin{array}{l}\text { Involves long overnight stay } \\
\text { planned group / individual / } \\
\text { small group. Limited numbers at } \\
\text { the extreme end but large } \\
\text { numbers in the Alps and other } \\
\text { accessible mountain terrain. }\end{array}$ \\
\hline $\begin{array}{l}\text { Bouldering } \\
\text { Short climbs, low enough to the ground so } \\
\text { that getting hurt is nearly impossible. Fastest } \\
\text { growing sector. Simple, no gear required. } \\
\text { Mainly indoor. }\end{array}$ & $\begin{array}{l}\text { High growth potential. Easy to } \\
\text { do, quick and interesting to do } \\
\text { in groups / families. Day trips } \\
\text { and as part of activities on longer } \\
\text { family holidays. }\end{array}$ \\
\hline $\begin{array}{l}\text { Sport climbing } \\
\text { Sport climbing describes climbing where the } \\
\text { anchors (typically bolts) are already placed } \\
\text { in the rock prior to climbing it. Sport routes } \\
\text { do require rope and other gear for safety, } \\
\text { but sport climbing is associated with shorter, } \\
\text { safer routes and more difficult movements } \\
\text { at the limit of a climber's physical ability. It } \\
\text { is safer, faster and less expensive than alpine } \\
\text { climbing. Fast growing sector. }\end{array}$ & $\begin{array}{l}\text { Large growth area for many } \\
\text { groups. Overnight stay possible. } \\
\text { Planned group / individual / } \\
\text { small group activity. Daytrips and } \\
\text { short weekend breaks also } \\
\text { possible. }\end{array}$ \\
\hline
\end{tabular}

contnd. 
Table 2 (contd.)

\begin{tabular}{|l|l|}
\hline \multicolumn{1}{|c|}{ Climbing types } & \multicolumn{1}{|c|}{ Sport Tourism Potential } \\
\hline $\begin{array}{l}\text { Klettersteig } \\
\text { Becoming popular in Europe. Using a a } \\
\text { harness and climbing on ladders with other } \\
\text { artificial metal safety material that is hung } \\
\text { up on the route. Outdoor family activity. }\end{array}$ & $\begin{array}{l}\text { High growth potential safe and } \\
\text { easy to do. Can form part of } \\
\text { wider family holiday as a } \\
\text { secondary activity. }\end{array}$ \\
\hline $\begin{array}{l}\text { Drytooling } \\
\text { Advanced form of sport climbing often done } \\
\text { as an indoor practice for mountaineering / } \\
\text { ice climbing. }\end{array}$ & $\begin{array}{l}\text { Limited sport tourism potential. A } \\
\text { minority compete. }\end{array}$ \\
\hline $\begin{array}{l}\text { Ice climbing } \\
\text { Like traditional climbing except that the } \\
\text { climber is scaling an ice formation (such as } \\
\text { a frozen waterfall or a glacier). Specialised } \\
\text { equipment needed. }\end{array}$ & $\begin{array}{l}\text { Small group of dedicated } \\
\text { followers. Is increasing but not at } \\
\text { a great participant rate. Indoor } \\
\text { ice climbing becoming very } \\
\text { popular for excursionist. }\end{array}$ \\
\hline $\begin{array}{l}\text { Builderingls like bouldering, but one climbs } \\
\text { on the sides of chimneys and buildings - } \\
\text { often done without ropes. }\end{array}$ & $\begin{array}{l}\text { Limited potential with small group } \\
\text { of followers. High chance of } \\
\text { incidental sport tourism as a } \\
\text { passive spectator. }\end{array}$ \\
\hline $\begin{array}{l}\text { Tree climbing Can be done with or without } \\
\text { ropes; depending on the height and length } \\
\text { of the tree. }\end{array}$ & $\begin{array}{l}\text { Growth area particularly at } \\
\text { competitive events in USA and } \\
\text { Canada. }\end{array}$ \\
\hline
\end{tabular}

Table 3. Climbing Methods

\section{Traditional climbing}

Requires carrying a rope and special equipment (metallic devices) that expand, twist, or wedge into cracks or holes in the rock. Rope is fed through karabiners or slings attached to the climbing rope. The combination of rope and protection will "catch" a lead climber in the event of a fall. More of a psychological test than sport climbing, because of the greater height exposure and the necessity in placing your own gear. It is of varying difficulty and endurance. This is linked to Alpine climbing (mountaineering) and ice climbing.

\section{Free climbing}

Like sport climbing except you use no rope. Dangerous. 
Table 3 (contd.)

\section{Aid climbing}

Climbing a wall that offen requires more than a day to climb, and therefore requires sleeping on natural ledges or hauling a portable ledge up the wall with you. Big wall routes are usually long, gruelling and high risk. Earliest of all rock climbing techniques. Large, multi-pitch wall climbs require strength, endurance, mental toughness and expert rope skills, as well as a tremendous amount of equipment of a more specialized nature. Linked to Alpine (Mountaineering) climbing.

\section{Mixed climbing}

Traditional and ice climbing in combination.

\section{Red point}

Competition climbing that provides many different climbing routes. Each route has a different level of difficulty and a unique point value commensurate to the level of difficulty. It has many variations. Part of sport climbing.

\section{On sight}

Used by National and World Cup difficulty climbing events Competitors are allowed one preview and one attempt on a route The height the climber achieves will determine the number of points awarded for the climb competitors will climb one at a time climbers are taken to an isolation area. Part of sport climbing.

\section{Flash}

Format where competitors can watch each other climb, talk to the other competitors and spectators about routes and exchange information. Part of sport climbing. 
Table 4. Competitions and events

\begin{tabular}{|c|c|}
\hline Competitions and Events & Sport Tourism Potential \\
\hline $\begin{array}{l}\text { (non) Sanctioned. A sanctioned climbing competition } \\
\text { will give points toward national or world ranking } \\
\text { rankings. A non-sanctioned climbing competition } \\
\text { does not provide points toward a ranking and is } \\
\text { usually just for fun, Within the UIAA, the Comite } \\
\text { Internacionale de Competition d'Escalade (ICC) } \\
\text { coordinates with member nations to oversee that } \\
\text { country's national team for competition on the World } \\
\text { Cup level. }\end{array}$ & Not applicable \\
\hline $\begin{array}{l}\text { Local } \\
\text { Not sanctioned. Prizes from local suppliers or } \\
\text { sponsors. Routes are set by local climbers or gym } \\
\text { staff. This format is the most flexible and is } \\
\text { predominantly for a fun, low stress social event. }\end{array}$ & $\begin{array}{l}\text { Day trips excursionist } \\
\text { individual or group. }\end{array}$ \\
\hline $\begin{array}{l}\text { Regional } \\
\text { Usually sanctioned. Prizes vary. Combination of cash } \\
\text { prize or gear. Routes are typically set by certified } \\
\text { course setters and the competition will have specific } \\
\text { rules.E.g. Bouldering - characterised by short routes } \\
\text { and high strength moves. Officially introduced } \\
\text { competitively in } 1998 \text {. }\end{array}$ & $\begin{array}{l}\text { Exciting spectator sport } \\
\text { and one where day trips } \\
\text { can be organised, } \\
\text { individual or in groups. } \\
\text { Possible overnight stay. }\end{array}$ \\
\hline $\begin{array}{l}\text { National } \\
\text { Sanctioned. Prize is typically a cash purse. National } \\
\text { team representative chosen for world competitions. } \\
\text { E.g. Speed climbing is enjoyable to watch and } \\
\text { probably the most marketable from a media } \\
\text { perspective. Climbers compete against time to see } \\
\text { who can reach the top of the route first. }\end{array}$ & $\begin{array}{l}\text { Exciting spectator sport } \\
\text { and one where short } \\
\text { overnight stay more } \\
\text { likely. Day trips rare. }\end{array}$ \\
\hline $\begin{array}{l}\text { International } \\
\text { International Union of Alpinist Associations (UIAA) } \\
\text { is the international sanctioning body for international } \\
\text { climbing competitions. Recognised by the } \\
\text { International Olympic Committee (IOC) as the } \\
\text { official body representing competition climbing. }\end{array}$ & $\begin{array}{l}\text { Overnight stay of longer } \\
\text { duration, combined with } \\
\text { other activities. }\end{array}$ \\
\hline
\end{tabular}

contnd. 
Table 4 (contd.)

\begin{tabular}{|c|c|}
\hline Competitions and Events & Sport Tourism Potential \\
\hline $\begin{array}{l}\text { Important Climbing Events } \\
\text { The World Cup Series of climbing competitions of } \\
\text { the best climbers in each country. Male and female } \\
\text { categories of each country have a competition } \\
\text { season. The climber with the most points is selected } \\
\text { as the World Cup winner. }\end{array}$ & $\begin{array}{l}\text { Participants (average per } \\
\text { event) } 80 \text { men and } 60 \\
\text { women from } 15 \text { to } 30 \\
\text { countries. Spectators } \\
\text { (average per event) } \\
1500-7000 \text { (Source } \\
\text { UIAA / ICC 2005). }\end{array}$ \\
\hline $\begin{array}{l}\text { World Championship } \\
\text { Held every two years on Olympic "off years". One } \\
\text { winner from each of the male and female categories. } \\
\text { The winners become the world champions and hold } \\
\text { the title for two years. }\end{array}$ & $\begin{array}{l}\text { Participants } 160 \text { men } \\
\text { and } 115 \text { women from } \\
31 \text { countries.Spectators } \\
6000-12000 \text { per } \\
\text { discipline, in total more } \\
\text { than } 25000 \text { over a three } \\
\text { day event. (Source } \\
\text { UIAAICC 2005). }\end{array}$ \\
\hline
\end{tabular}

\section{Sport tourism and climbing}

Climbing sport tourism is not new. Climbing can be traced back to early civilisation but it is widely accepted that the birthplace of Mountain climbing dates back to 1741 when a group climbed Montavert, Chamonix in the French Alps. It became an official sport in 1856 (Zauhar 2004).

Paralleled with an increase in recent years in outdoor activity and rock climbing, there has also been a steadily rising interest in the field of sport and tourism. The term sport tourism being used to indicate sport related travel (Gibson 2002). Researchers have attempted to define this area but at present there is no clear cut definition of what constitutes sport or tourism and thus attempting to qualify sport tourism is again fraught with difficulties. The establishment of a core body of knowledge is one area in where progress can be made. Indeed Gibson (2004) suggests that it is now time to move on from the "what is and who" of sport tourism to the "why".

The interest and popularity of sport tourism over the last 15 years has attracted attention at an academic level. This paper is not intended to explore the beginnings and debate surrounding the definitions and descriptions of sport tourism; this is well documented through the Journal of Sport Tourism (in particular Vol. 9 No. 
3,2004 ), various other publications and conference themes (Gammon and Kurtzman (Eds) 2002) and the work of the Sport Tourism International Council (STIC). For a comprehensive analysis of the sport tourism literature see Higham (2005), Ritchie and Adair (2004), Weed and Bull (2004), Hinch and Higham (2003). For motivational aspects of sport, tourism and sport tourism see Robinson and Gammon (2004), Ryan (2003), (1995), Roberts (1992), Dann (1981) and Iso-Ahola, (1980), Calder and Staw (1975).

However the debate about what constitutes sport and the definitions relating to whether a tourist is someone who spends a night away from their home (excluding day trippers / excursionists) will undoubtedly continue. For the purposes of this paper sport tourism and climbing sport tourism follows the definition and application of the Gammon and Robinson framework (1997).

Robinson and Gammon (2004), Gammon and Robinson (1997) devised a conceptual framework where the sport tourist cold be categorised depending upon their primary and secondary reasons for travel. This is outlined below:

Figure 1. The Gammon and Robinson motivational framework (1997) and its application Robinson and Gammon (2004).

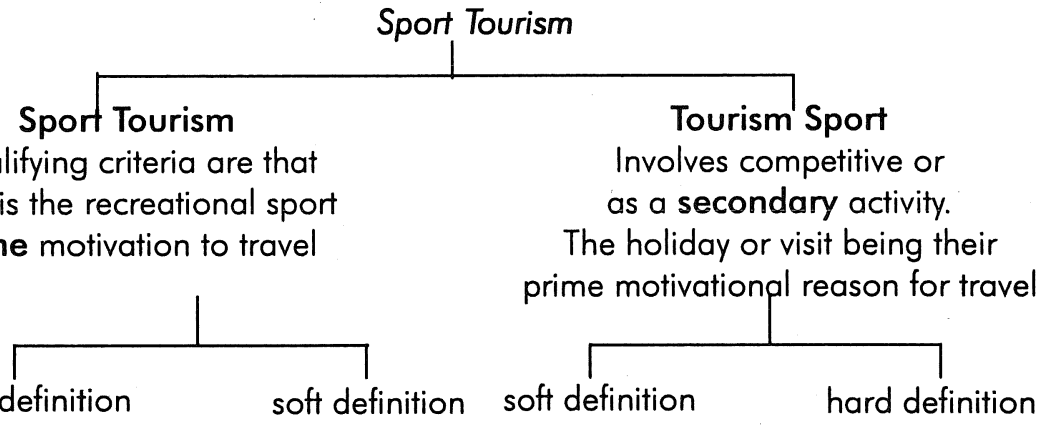

COMPETITIVE RECREATIONAL INCIDENTAL

ENRICHMENT

\begin{tabular}{|c|c|c|c|}
\hline $\begin{array}{c}\text { passive or active } \\
\text { participation at } \\
\text { a competitive } \\
\text { sporting event }\end{array}$ & $\begin{array}{c}\text { Primarily active } \\
\text { recreational } \\
\text { participation } \\
\text { in sport }\end{array}$ & $\begin{array}{c}\text { Visitors who engage } \\
\text { in some minor form } \\
\text { of sport or leisure; } \\
\text { their participation } \\
\text { is purely incidental }\end{array}$ & $\begin{array}{c}\text { Tourists who as } \\
\text { a secondary } \\
\text { reinforcement } \\
\text { passively or } \\
\text { actively participate } \\
\text { in sport }\end{array}$ \\
\hline
\end{tabular}


Definition: individuals and/or groups of people who actively or passively participate in competitive or recreational sport, whilst travelling to and/or staying in places outside their usual environment (Gammon and Robinson 1997).

A motivational framework is suggested (based on primary and secondary motivations) as an aid to understand the sport tourism phenomena. Since climbing is motivationally complex it may be better to adopt the Robinson and Gammon approach where:

"It is unrealistic to list all the possible motivational variations, but more enlightening to suggest that a relationship exits based upon primary and secondary considerations." (Robinson and Gammon, 2004:1).

They go on to say

"These combined collective motives illustrates that at this point in time it is unrealistic to identify and link up the almost countless motivational variables found in both sport and tourism. It may be wiser to take a broader view of the sport-tourism nexus by first suggesting that there exists a motivational duality which is both synergetic and reciprocal". (Robinson and Gammon, 2004:3).

By applying the Robinson and Gammon 2004 motivational framework, climbing can be categorised by primary and secondary motivations and indicated in the framework (see figure 2).

Certainly hard climbing sport tourists can easily be identified but their involvement is dominantly active participation and not as passive spectators. Recreational climbing is by far the dominant activity practiced although a distinction can generally be made here between indoor and outdoor climbing and traditional versus sport climbing. Profiling a particular sport provides an overview for possible market penetration for many organisations interested in developing a sport tourism product. In this instance an attempt has been made to incorporate climbing into the framework at both an international and national level (see figures 2 and 3 ).

The national framework example (figure 3), incorporating climbing associated with The Netherlands is interesting because it is a very popular sport within the Netherlands yet there is virtually no possibility to naturally climb within the country due to its mainly featureless geographical relief. Thus participants will have to travel and /or adapt to the indoor scene to achieve their goal of climbing. This makes it an ideal sport tourism case study. 
Examples

CLIMBING SPORT and TOURISM
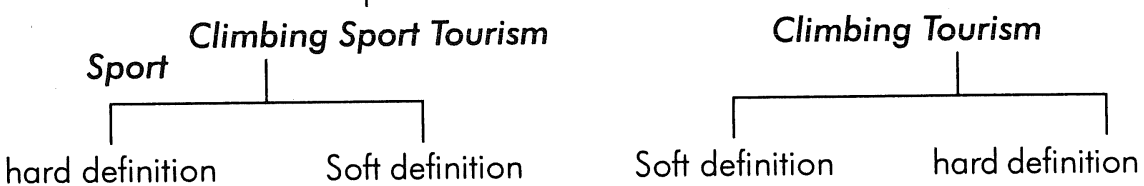

\begin{tabular}{|c|c|c|c|}
\hline $\begin{array}{l}\text { passive or active } \\
\text { participation } \\
\text { at a competitive } \\
\text { sporting event }\end{array}$ & $\begin{array}{c}\text { Primarily } \\
\text { active } \\
\text { recreational } \\
\text { participation } \\
\text { in sport }\end{array}$ & \begin{tabular}{|c|} 
Visitors who \\
engage in some \\
minor form of \\
sport or leisure; \\
their \\
participation is \\
purely incidental
\end{tabular} & $\begin{array}{c}\text { Tourists who } \\
\text { as a secondary } \\
\text { reinforcement } \\
\text { passively or } \\
\text { actively } \\
\text { participate in } \\
\text { sport }\end{array}$ \\
\hline $\begin{array}{l}\text { Events 2004: } \\
\text { Asian Championship, } \\
\text { Jeolla Nam Do, Korea. } \\
\text { World cup Shanghai, } \\
\text { China. } \\
\text { World Youth Championship } \\
\text { Edinburgh, Scotland. } \\
\text { European Youth Cup, Imst, } \\
\text { Austria. } \\
\text { European Championship, } \\
\text { Lecco, Italy } \\
\text { Central-South American } \\
\text { Championship - S. Antonio } \\
\text { de los Altos, Venezuela. } \\
\text { Spiderkids - Kids Climbing } \\
\text { Competition of Aggtelek, } \\
\text { Hungary. Boulder World } \\
\text { Cup China European Tree } \\
\text { climbing Competition } \\
\text { Maastricht Vancouver, } \\
\text { Canada, Buildering } \\
\text { contest. }\end{array}$ & $\begin{array}{l}\text { Independent } \\
t \quad \text { o u r } \\
\text { operators } \\
\text { of fering } \\
\text { cli mb ing } \\
\text { holidays. } \\
\text { Cli m b ing } \\
\text { clubs offering } \\
\text { cli m b ing } \\
\text { holidays. } \\
\text { Visits } \\
\text { cli mb ing } \\
\text { walls. } \\
\text { Individuals } \\
\text { arranging } \\
\text { independent } \\
\text { climb ing } \\
\text { holidays. }\end{array}$ & $\begin{array}{l}\text { This category is } \\
\text { open to } \\
\text { interpretation and } \\
\text { includes all } \\
\text { climbing related } \\
\text { facilities that } \\
\text { tourists encounter } \\
\text { during their stay, } \\
\text { though they } \\
\text { wo u I d n t } \\
n \text { e e s s a ril y } \\
\text { consider using } \\
\text { them. This } \\
\text { category may form } \\
\text { a catalyst for other } \\
\text { c I } \mathrm{i} \text { b i n g } \\
\text { involvement in the } \\
\text { framework at a } \\
\text { later stage. } \\
\text { Examples include } \\
\text { tree climbing, } \\
\text { bo u I d e ring, } \\
\text { scrambling. }\end{array}$ & $\begin{array}{l}\text { Holidays in the } \\
\text { countryside. } \\
\text { Hiking and } \\
\text { scrambling up } \\
\text { hills / mountains. } \\
\text { City breaks e.g. } \\
\text { U.K. Sheffield, } \\
\text { the Foundry. } \\
\text { Visitorattractions } \\
\text { including rock } \\
\text { climbing, e.g. } \\
\text { rock climbing at } \\
\text { the first world } \\
\text { plaza indoor } \\
\text { theme park } \\
\text { Tioman Island, } \\
\text { G e } n+i n g \\
\text { Malaysia. } \\
\text { Rock Climbing } \\
\text { Museums: } \\
\text { Proposed - } \\
\text { Yosemite, USA. }\end{array}$ \\
\hline
\end{tabular}

Figure 2: Application of framework to a Sport CLIMBING 
Examples

CLIMBING SPORT and TOURISM

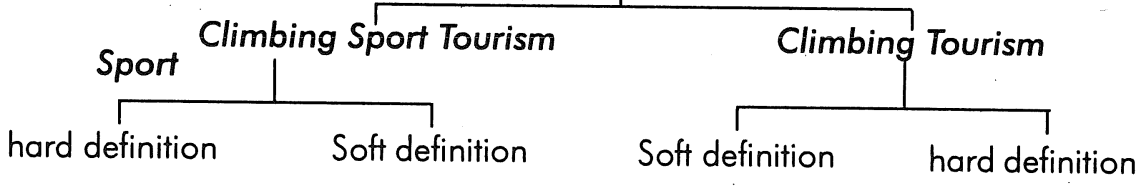

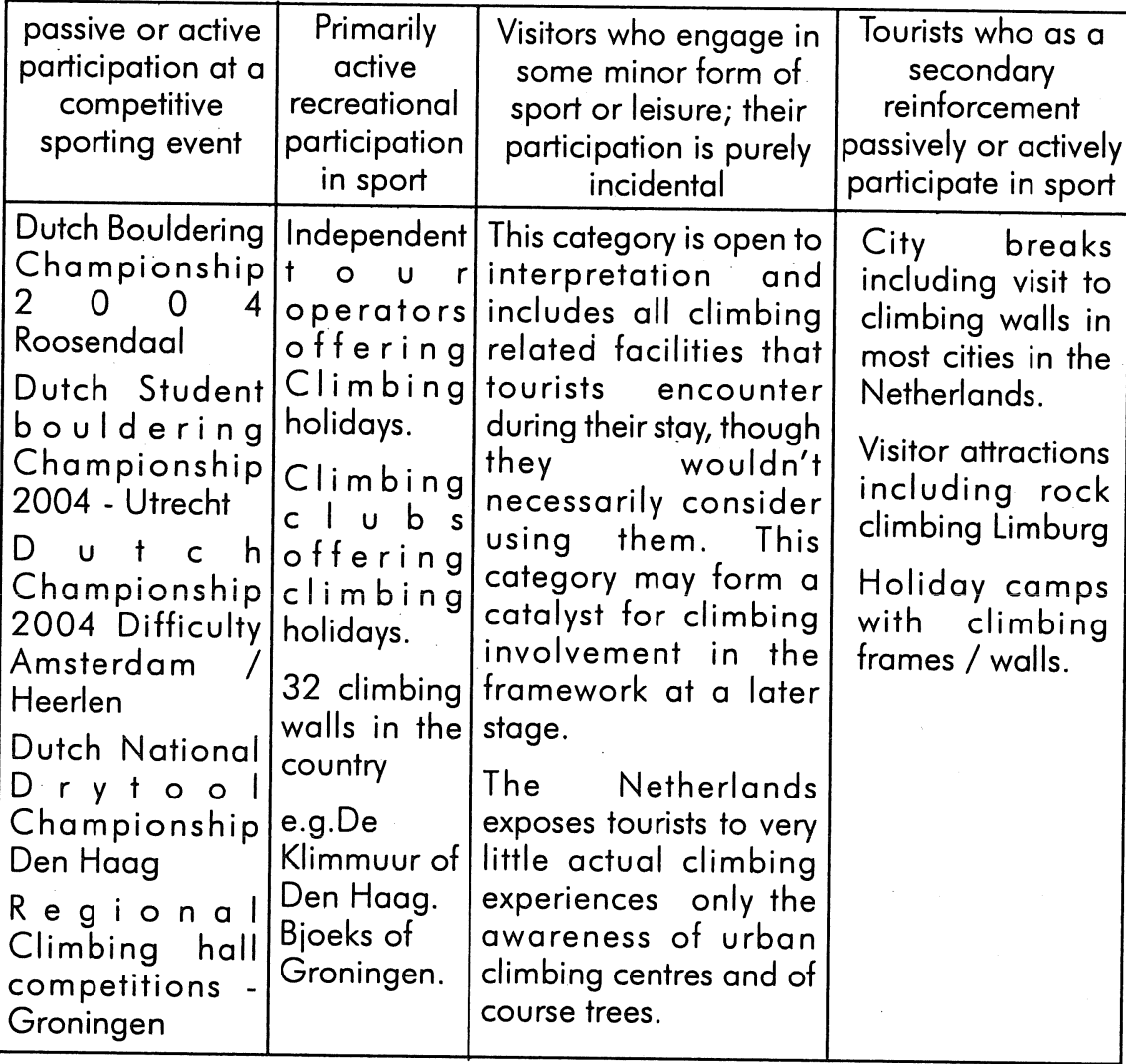

Figure 3: Application of framework to climbing - A Country profile the NETHERLANDS 
Table 5: Dutch sport tourism climbing possibilities

\begin{tabular}{|l|l|l|}
\hline \multicolumn{1}{|c|}{ Climbing type } & \multicolumn{1}{|c|}{ Length of stay } & \multicolumn{1}{c|}{ Location } \\
\hline $\begin{array}{l}\text { Indoor / outdoor walls } \\
\text { (artificial) }\end{array}$ & Short one day & $\begin{array}{l}\text { Cities in The Netherlands } \\
\text { e.g. Groningen the } \\
\text { 'Boekjels' }\end{array}$ \\
\hline $\begin{array}{l}\text { Outdoor climbing } \\
\text { (natural) }\end{array}$ & Short break - weekend & $\begin{array}{l}\text { Dinant, Belgium. } \\
\text { Ibbenbüren, Germany. }\end{array}$ \\
\hline $\begin{array}{l}\text { Outdoor climbing } \\
\text { (natural) }\end{array}$ & Long stay $>5$ days & European Alps \\
\hline
\end{tabular}

The usefulness of applying climbing to the framework is its applicability to a number of planning and marketing aspects. Interestingly Weed and Bull (2004) attempt to describe the sports tourism phenomenon through a wide ranging and multifaceted conceptualised link:

"Sport tourism is a social, economic and cultural phenomenon arising from the unique interaction of activity, people and place." (Weed and Bull, 2004:37).

Who and where you share this experience and activity with is of course important. From a climbing perspective as a sport tourism example the use of activity, people and place cannot be better exemplified. Climbing in the Alps conjures up its own images of beauty, landscapes and natural scenery. This coupled with the motivations outlined in table one makes this a unique contributing activity. However since one of the major extrinsic motivations to come out of the research in this area has been friendship then the added value of climbing partners and like minded people make climbing a part of the unique experience that sport tourism can offer. This 'link' is important when considering primary and secondary motivations.

\section{Conclusions and Recommendations}

Climbing in its general sense is experiencing growth primarily through active but also to a lesser extent passive participation throughout the world. The introduction of sport climbing, with the growth of a wide range of competitions through the formation of the ICC, (within the official umbrella of the UIAA) all testify to this. This once elite pastime has now developed into a variety of recreational and competitive activities both active and passive that warrant attention in respect of sport tourism. The sport tourism potential of climbing is huge. Large numbers in 
many countries participate, as individuals or as part of clubs and societies at all levels. Sport tourism ranges from day trips to short breaks to longer holidays and to expeditions, spanning the whole spectrum of lengths of stay and covering large areas of the planet geographically. The advent of sport climbing has opened up a whole new market to the young and families. Understanding these trends is fundamental in developing the right sport tourism packages for all concerned. An activity which necessitates in many cases travel involving like minded people in often beautiful and unusual surroundings provides the perfect sport tourism scenario.

From the Gammon and Robinson framework, (2004) it soon becomes apparent that there appears to be a sharp contrast in climbing markets - those that traditionally climb and the sport climbers. The market for these appears also to be radically different and further research is needed to now clearly identify the segments of these markets. This is further complicated by the indoor (artificial) scene, outdoor (artificial and natural) scene and the winter and summer climbing fraternity.

It is difficult to imagine the future scenario. The diversity of climbing in recent decades coupled with the ever increasing imagination of the indoor / outdoor climbing centres has made the sport accessible for many target groups in all it guises. The motivational aspects of climbing as expressed by the pure mountain climber as opposed to the 'fun play' ways in which many of the indoor areas have been established also appear to be in sharp contrast. There are those that climb primarily for intrinsic and those that climb primarily for extrinsic reasons. Although as established through multiple motivators it is more than likely a combination of complex motivational factors are responsible for such diverse climbing activities. The Robinson and Gammon framework attempts to simplify this and categorises areas of potential market segmentation where consumers can be targeted.

No one sole or multiple motivators can account for the numerous ways in which people climb. Thus attempting to recognise who climbs is very difficult and in many ways a meaningless tasks. However there are areas of the sport which are gaining in popularity and it is this target market that attention should be focused.

Group travel versus individual travel is a difficult area in climbing and determining this needs further research. Similarly organised group travel versus tour operator travel is again a dichotomy of the sport which needs further investigating.

There are many reasons why people decide to actively or passively participate in climbing. These revolve round sport and tourism motives coupled with the intrinsic 
and extrinsic motives identified. The Sport Tourism Framework appears a simplified way to illustrate these relationships by categorising the climbing sport tourist based upon primary and secondary motives, linked to competitiveness, recreation, activity and passivity.

However it also provides a benchmark for those organisations offering climbing sport tourist experiences; outlining what is currently available against what they may want to develop for the future.

Further research is needed in the profiling of the different climbing activities and assessing the climbing sport tourism motives to better understand the climber.

The increasing importance of sport climbing should not be underestimated. Sport climbing has become not only an accepted competitive sport but it also acts as a social stimulant. It is also part of the educational curriculum in many countries. The disabled and other under privileged groups are also part of many special programmes. This rapid growth and has also led to the development of sport climbing in many developing countries. Thus the globalisation of the sport geographically means that it acts as a serious alternative activity to people of all ages all over the world.

What is an interesting paradox is that the same time the sport is being popularised all over the world, the reduction in risk characterised by sophisticated guide books, training programmes, specialised equipment and safe indoor walls makes many of the stimuli that people begin the climbing experience to become irrelevant or to operate at least at a lower level.

\section{References}

1. Boyd, J., \& Munroe, K,J. (2003). The Use of Imagery in Climbing. Athletic Insight: Online Journal of Sport Psychology 5 (2).

2. British Mountaineering Council (BMC) Participation Survey (2003). Retrieved March, 2005 from http://www.thebmc.co.uk/safety/advice/articles/ParticipationStats03.pdf

3. Calder, B.J and Staw, B. (1975). Self-perception of Intrinsic and Extrinsic. Motivation. Journal of Personality and Social Psychology, 31 (4), pp. 599-605.

4. Campbell R, N. (1997). Trends and motives affecting participation in active outdoor pursuits: the case of climbing. Department of Psychology, University of Stirling Commissioned by Scottish Natural Heritage, Access \& Recreation Division, Retrieved March, 2005 from http:// www.stir.ac.uk/staff/psychology/rncl/SNH\%2Oreport/SNH.html

5. Carr, A. (1998). Mountain Madness: Guided mountaineering in New Zealand's Southern Alps. Retrieved March, 2005 from http://wmw.business.ołago.ac.nz/tourism/research/electronicpubs/ index.html 
6. Catton W.R.J. (1969). Motivations of wilderness users. Woodlands Section, Pulp and Paper Magazine of Canada December 1969, 19:121-126.

7. Cordell, K. (2004). Outdoor Recreation for 21 st Century America. A Report to the Nation: The National Survey on Recreation and the Environment. State College, Pennsylvania.Venture Publishing, Inc.

8. Csikszentmiyalhi, M. (1975). Beyond Boredom and Anxiety. San Francisco, CA: Jossey-Bass. 9. Csikszentmihalyi, M. (1990). Flow: the psychology of optimal experience. New York: Harper/
Collins.

10. Dann, G.M.S. (1981). Tourist motivation: An appraisal. Annals of Tourism Research 8 (2), 187.

11. Deci, E. L., \& Ryan, R. M. (1985). Intrinsic motivation and self-determination in human behavior. New York: Plenum Publishing Co.

12. Deci, E. L., \& Ryan, R. M. (Eds.), (2002). Handbook of self-determination research. Rochester, NY: University of Rochester Press.

13. Ewert, A. (1985). Why people climb: The relationship of participant motives and experience level to mountaineering. Journal of Leisure Research, 17(3), 241-250.

14. Freischlag, J., \& Freischlag, T. (1993). Selected psycho-social, physical, and technical factors among rock climbers: A test of the flow paradigm. Applied Research in Coaching and Athletics Annual, 24, 24-37.

15. Gammon, S. and Kurtzman, J. (Eds.) (2002). Sport Tourism Principles and Practice, Eastbourne, UK: Leisure Studies Association (LSA) 76.

16. Gammon, S. and Robinson, T. (1997). Sport Tourism: A Conceptual Framework, Journal of Sport Tourism, 4 (3).

17. Gibson, H., J. (2002). Sport Tourism at a crossroad? Considerations for the future. In S. Gammon, and J. Kurtzman, (Eds) Sport Tourism Principles and Practice, (pp 123-140). Eastbourne, UK: Leisure Studies Association, 76.

18. Gibson, H, J. (2004). Moving beyond the "what is who" of sport tourism to understanding "why". Journal of Sport Tourism, 9 (3).

19. Health and Safety Executive / Local Authorities Enforcement Liaison Committee (HELA) available at http://www.hse.gov.uk/lau/lacs/47-15.htm

20. Higham, J. (Ed), (2005). Sport Tourism Destinations, issues opportunities and analysis. Oxford: Butterworth Heinemann.

21. Hinch, T. and Higham, J. (2003). Sport Tourism Development. Channel View Publications. Clevedon.

22. Houlihan, B. (2004). Sport and Society, London, Sage.

23. Iso-Ahola, S. (1980). The Social Psychology of Leisure and Recreation. Dubuque, IA: William Brown.

24. Journal of Sport Tourism (2004). 9 (3).

25. Kurtzman, J. and Zauhar, J. (1995). Agency Reports. Tourism Sports International Council. Annals of Tourism Research Vol. 22 No. 3 pp 707-708 
26. Maguire, J. (2004). Handbook of Sport Studies, London, Sage.

27. Magni, G., Rupolo G., Simini G., De Leo D. \& Rampazzo, M. (1985). Aspects of the personality and psychology of high-altitude mountain climbers. International Journal of Sports Psychology, 11: 12-19.

28. Meier, J.F. (1980). Is the risk worth taking? In Leisure Today: Selected Readings. Volume Two. F.W. Martin (editor), USA.

29. Mclntyre, N. (1992). Involvement in risk recreation. A comparison of objective and subjective measures of engagement. Journal of Leisure Research, 24(1), 64-71.

30. Mitchell, R. G. (1983). Mountain Experience: the Psychology and Sociology of Adventure. Chicago: University of Chicago Press

31. Ritchie, B. \& Adair, D. (Eds.) (2004). Sport Tourism inter-relationships, impacts and issues. Channel View Publications, Clevedon.

32. Roberts, G. C. (Ed.) (1992). Motivation in Sport Exercise. Leeds: Human Kinetics.

33. Robinson, D.W. (1985). Stress seeking: selected behavioral characteristics of elite rock climbers. Journal of Sport Psychology, 7: 400-404.

34. Robinson, T. and Gammon, S. (2004). A question of Primary and Secondary Motives: Revisiting and Applying the Sport Tourism Framework, Journal of Sport Tourism, 9 (3).

35. Rossi, B and Cereatti, L. (1993). Sensation seeking in mountain athletes as assessed by Zuckerman's Sensation seeking scale. International Journal of Sport Psychology, 24: 417-431

36. Ryan, C. (1995). Researching Tourism Satisfaction: Issues, Concepts, Problems. London: Routledge.

37. Ryan, C. (Ed.) (2003). The Tourist Experience. London: Continuum.

38. Walter, J.A. (1984). Death as recreation: armchair mountaineering. Leisure Studies, 3: 67-76

39. Weed, M. and Bull, C. (2004). Sports Tourism. Oxford: Butterworth- Heinemann.

40. Zauhar (2004). Historical perspectives of sports tourism, Journal of Sport Tourism. 9 (1). 


\section{Websites}

http://gorp.away.com/gorp/activity/climb.htm

www.psych.rochester.edu/SDT/index.html

http://www.abc-of-rockclimbing.com/whygorockclimbing.asp http://www.athleticinsight.com

http://www.cbs.nl

http://www.climbing.com

http://www.indoorclimbing.com

http://www.icc-info.org/

http://www.nkbv.nl

http://www.olympic.org/uk/organisation/

if/fi_uk.asp?id_federation $=37$

http://www.rockclimbing.com/

http://www.sport.nl

http://www.srs.fs.usda.gov/trends/recupdate0907.pdf

http://www.sptourism.net/

http://www.thebmc.co.uk/

http://www.viaa.ch

http://www.viaaclimbing.com/

http://www.ukclimbing.com/

http://www.usaclimbing.org/

http://www.womenclimbing.com
Commercial encyclopaedic resource for outdoor recreation.

Home page of E. L. Deci, R. M. Ryan

Applications of SelfDetermination Theory to sport and exercise.

Commercial rock climbing portal. Athletic Insight' The Online Journal of Sport Psychology.

Dutch Central Bureau of Statistics.

Commercial climbing magazine and shop.

Source for amateurs interested in indoor climbing.

International Council for Competition Climbing.

The Royal Dutch Climbing Federation.

The International

Mountaineering and Climbing Federation.

Amateur rock climbing site.

Netherlands Olympic Committee

* Netherlands

Sport Confederation (NOC*NSF).

American Outdoor Statistics.

Sport Tourism International Council.

British Mountaineering Council.

International Mountaineering and Climbing Association Union Internationale des Associations D'Alpinisme).

International Council for Competition Climbing.

English climbing site with climbing related links.

The National Governing body of competition climbing in the USA.

Women's only climbing site. 